\title{
Local mineral dust transported by varying wind intensities forms the main substrate for loess in Kashmir
}

\author{
Christian Zeeden ${ }^{1}$, Jehangeer Ahmad Mir ${ }^{2}$, Mathias Vinnepand ${ }^{1}$, Christian Laag ${ }^{1,3}$, Christian Rolf ${ }^{1}$, and \\ Reyaz Ahmad Dar ${ }^{2}$ \\ ${ }^{1}$ Rock Physics \& Borehole Geophysics, Leibniz Institute for Applied Geophysics (LIAG), 30655 Hanover, Germany \\ ${ }^{2}$ Department of Earth Sciences, University of Kashmir, Srinagar, 190006, India \\ ${ }^{3}$ Institut de Physique du Globe de Paris, Université de Paris, CNRS, Paris, 75005, France
}

Correspondence: Christian Zeeden (christian.zeeden@leibniz-liag.de)

Relevant dates: $\quad$ Received: 4 May 2021 - Revised: 21 June 2021 - Accepted: 23 July 2021 Published: 24 August 2021

How to cite: $\quad$ Zeeden, C., Mir, J. A., Vinnepand, M., Laag, C., Rolf, C., and Dar, R. A.: Local mineral dust transported by varying wind intensities forms the main substrate for loess in Kashmir, E\&G Quaternary Sci. J., 70, 191-195, https://doi.org/10.5194/egqsj-70-191-2021, 2021.

\section{Introduction and site descriptions}

Airborne mineral dust particles of dominantly silt size are the main substrate for loess deposits, which provide valuable and widespread palaeo-environmental archives. Especially during the Quaternary period, loess-palaeosol sequences (LPSs) formed through consolidation and largely climate-dependent post-depositional modifications of mineral dust, e.g. along the mid-latitudes in Eurasia. The enormous spatial spread of these archives exceeds the extent of any other Quaternary terrestrial sediment record. Consequently, LPSs are a key for studying the impact of oscillating and competing supraregional climate systems to sub-systems on diverse temporal and spatial scales. While Eurasian LPSs have been decently studied (e.g. Fischer et al., 2021; Jia et al., 2018; Zeeden et al., 2016; Vlaminck et al., 2016), information on age and physical properties of equivalents across the Indian subcontinent remains sparse (Dar and Zeeden, 2020). This limits our understanding of the origin of loess deposits and associated major wind directions and wind intensities for the Indian subcontinent throughout the Quaternary and how these factors differ from locations across Eurasia. Studies on Kashmir loess led to valuable stratigraphic descriptions (Bronger et al., 1987) and a first temporal frame- work (Singhvi et al., 1987), but few physical proxy data are available (Dar and Zeeden, 2020, and references therein). In this study, we present a first high-resolution investigation of room-temperature magnetic susceptibility and grain size data of loess deposits in the Kashmir region and compare our results with these from other LPSs in Eurasia. We aim to pave the way for further studies addressing differences in palaeo-environmental conditions between the Indian subcontinent and Eurasia, which are likely to reflect the impact of competing supra-regional climate systems (Indian monsoon, westerlies) varying over time.

In this study, we focus on the Wanihama section $\left(34^{\circ} 10^{\prime} 05.7^{\prime \prime} \mathrm{N}, 74^{\circ} 51^{\prime} 03.5^{\prime \prime} \mathrm{E}\right) \sim 4 \mathrm{~km}$ NE of Srinagar and the Khan Sahib section $\left(33^{\circ} 56^{\prime} 08.9^{\prime \prime} \mathrm{N}, 74^{\circ} 39^{\prime} 29.5^{\prime \prime} \mathrm{E}\right)$, $\sim 30 \mathrm{~km} \mathrm{SW}$ of Srinagar (both in Kashmir, Fig. 1). The sections were sampled continuously in $0.02 \mathrm{~m}$ resolution. Stratigraphic descriptions of the profiles are from bottom to top, in order of deposition. Only limited material could be removed from the hardened deposits at the outcrop behind the Wanihama Middle School (see Fig. 1a, c), where sampling was conducted in 2019. The base of the outcrop is characterised by chestnut-coloured lacustrine loamy and sandy deposits with no visible bedding. From 0.2 up to $0.5 \mathrm{~m}$, sediments are enriched with silty material whilst the sand content 

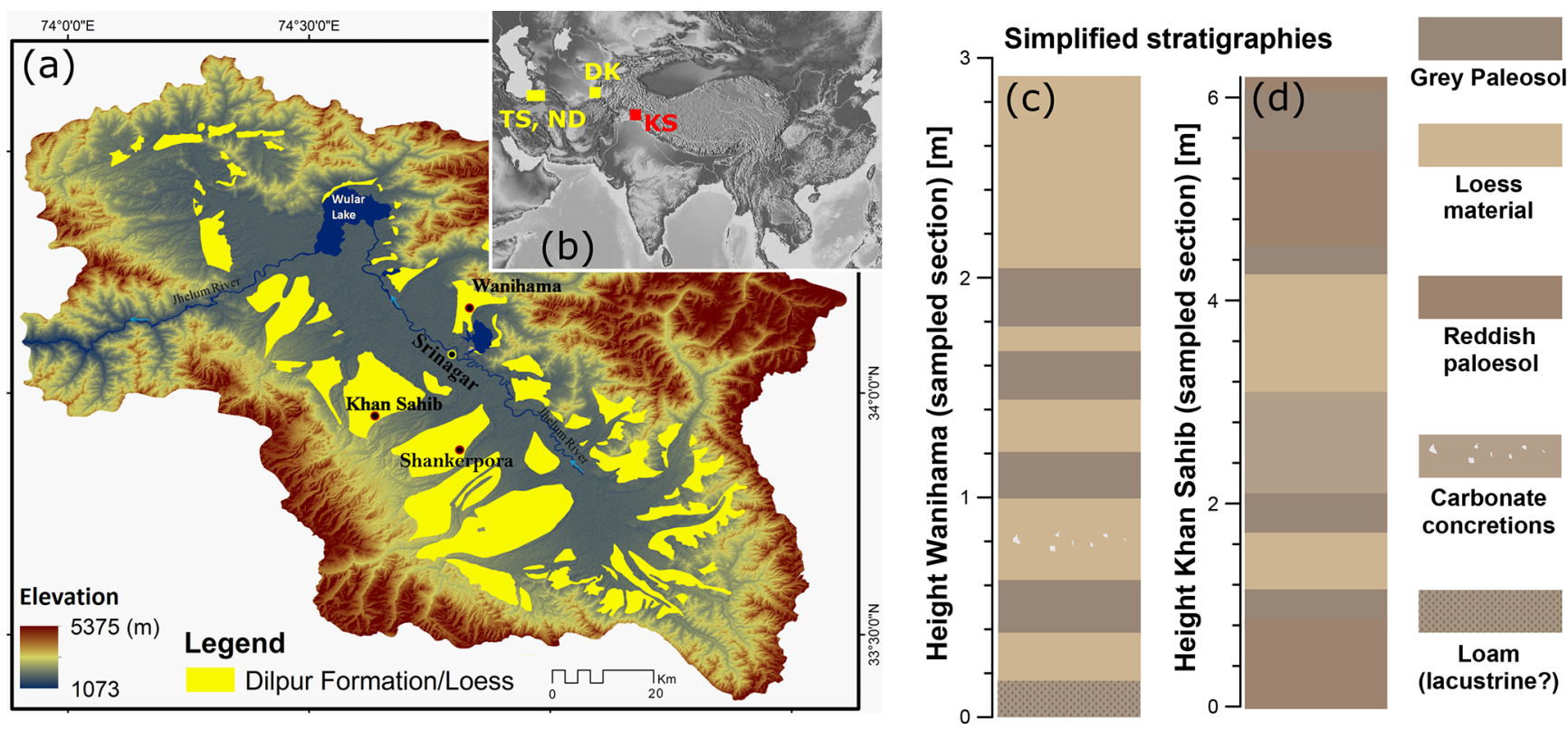

Figure 1. (a) Distribution of loess in Kashmir and (b) location of the studied Wanihama and Khan Sahib sections in supra-regional and regional context (after Dar and Zeeden, 2020). KS denotes Kashmir loess, DK Darai Kalon, and TS and ND Toshan and Now Deh, respectively. Profile sketches of the profiles Wanihama (c) and Khan Sahib (d, on the right) show alternating loess and palaeosol units indicating climate sensitivity of the archives. Sampling resolution was $0.02 \mathrm{~m}$.

decreases distinctly. Note that this interval contains varying amounts of $\sim 1 \mathrm{~mm}$ sized carbonate nodules. Until $0.8 \mathrm{~m}$, the sediment gets lighter until a medium silt component dominates the grain size range (prevailing up to the top of the sampled section). From 0.8 up to a height of $1.70 \mathrm{~m}$ the hues of the record turn brown again with a distinct gradient towards darker brown hues at the top of this interval. Ochrecoloured sediments occur from $\sim 1.7-1.8 \mathrm{~m}$. These are followed by brown silt until $2.2 \mathrm{~m}$. The part from $2.2 \mathrm{~m}$ up to the top of the LPS is characterised by light ochre silt including preserved palaeo-root channels.

In 2020, we sampled $6.20 \mathrm{~m}$ of the Khan Sahib section (Fig. 1a, d). Sampling started at the base within a brown silt. Palaeosols with clearly enhanced clay contents and (sub)polyhedric structures are identified at $\sim 1,2,4.5$ and $5.8 \mathrm{~m}$ height of the LPS. These at 2, 4.5 and $5.8 \mathrm{~m}$ exhibit a grey to brown colour. In contrast, the palaeosol at $\sim 1 \mathrm{~m}$ height is brown to black and mostly clay- and organic-rich. All palaeosols are separated by lighter packages of loess or weaker pedogenesis. Due to similarities of the stratigraphies of the records under study with parts of a $17 \mathrm{~m}$ thick LPSs at Shankerpora, Kashmir (Fig. 1a), temporally placed into the last glacial cycle (Meenakshi et al., 2018), we start from the premise that both studied sections formed during the late last glacial cycle in the interval between oxygen isotope stages (OISs) 4 to 2.

\section{Geophysical sediment properties: methods and results}

For magnetic susceptibility measurements we dried, disintegrated, and homogenised the samples and transferred the material into $6.4 \mathrm{~cm}^{3}$ non-magnetic plastic boxes. Subsequently, the mass-normalised magnetic susceptibility $(\chi)$ was measured using a MAGNON VFSM susceptibility bridge. Frequencies of $505 \mathrm{~Hz}$ (low frequency; $\chi_{\mathrm{lf}}$ ) and $5050 \mathrm{~Hz}$ (high frequency; $\chi_{\mathrm{hf}}$ ) and a field intensity of $400 \mathrm{~A} \mathrm{~m}^{-1}$ were used. $\Delta \chi$ denotes the difference between $\chi_{\mathrm{lf}}$ and $\chi_{\mathrm{hf}}$ and is indicative of fine magnetic grain sizes. Grain sizes were determined using a Beckman Coulter LS 13320 PIDS using methods as described in Vlaminck et al. (2016).

The $\chi_{\text {lf }}$ ranges from $25 \times 10^{-8}$ to $144 \times 10^{-8} \mathrm{~m}^{3} \mathrm{~kg}^{-1}$ with a mean of $82 \times 10^{-8} \mathrm{~m}^{3} \mathrm{~kg}^{-1}$ at Wanihama (Fig. 2a). At the Khan Sahib section, the $\chi_{\text {lf }}$ ranges from $28 \times 10^{-8}$ to $170 \times 10^{-8} \mathrm{~m}^{3} \mathrm{~kg}^{-1}$ with a mean of $75 \times 10^{-8} \mathrm{~m}^{3} \mathrm{~kg}^{-1}$ (Fig. 2b). The $\Delta \chi$ lies in the range from $2.5 \%$ to $10.7 \%$ for the Wanihama and from $3.1 \%$ to $10.9 \%$ for the Khan Sahib section. The grain size distributions plotted in Fig. 3 have a dominant peak at the boundary from middle to coarse silt around $10-30 \mu \mathrm{m}$ throughout, with rather small differences between soils and loess. All but one sample from $0.98 \mathrm{~m}$ of the Wanihama section exhibit at least one additional component with a local maximum in grain size ranging around 50-500 $\mu \mathrm{m}$ (Fig. 3). Overall, the palaeosol samples exhibit finer modes than the loess samples. The two loess samples (from Wanihama $1.48 \mathrm{~m}$, Khan Sahib $6.18 \mathrm{~m}$ ) contain dif- 

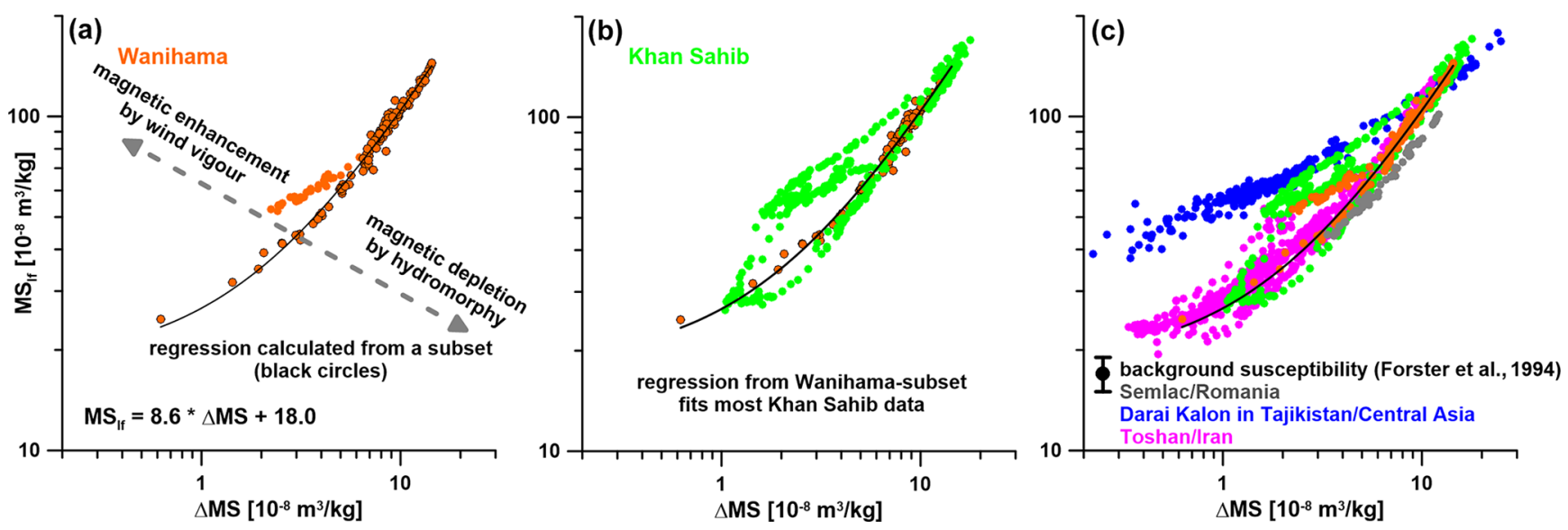

Figure 2. Magnetic enhancement at (a) Wanihama including an enhancement line for the lower $2.4 \mathrm{~m}$. (b) Enhancement plot for Khan Sahib including the data from Wanihama. (c) Data from both Kashmir localities with comparison to reference data from Semlac, Romania (Zeeden et al., 2016); Darai Kalon, Tajikistan (Jia et al., 2018); and Toshan, Iran (Vlaminck et al., 2016). Note that only data from the last glacial-interglacial cycle are plotted and that plots are double logarithmic.

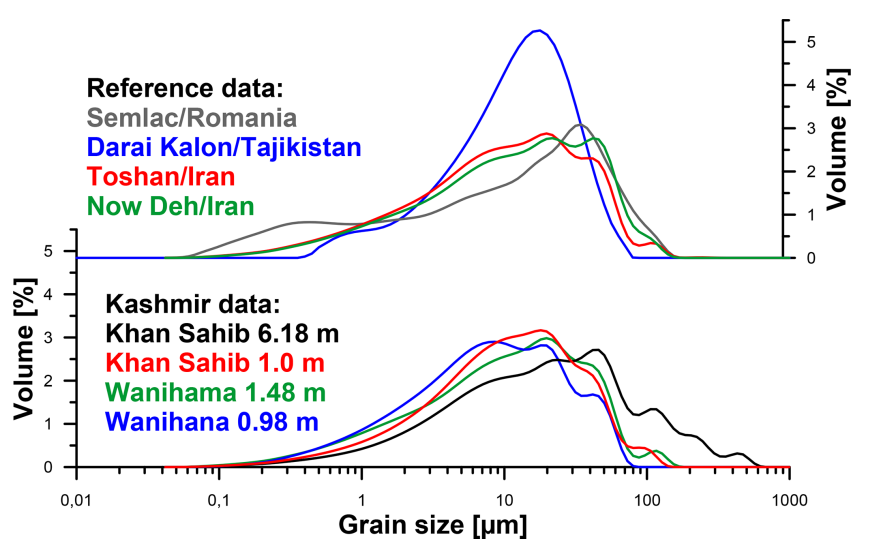

Figure 3. Grain size properties of Kashmir loess, also in comparison with data from Semlac, Romania; Toshan, Iran; and Now Deh, Iran. Reference data from $\sim 30 \mathrm{ka}$ are plotted for Semlac and Darai Kalon (Zeeden et al., 2016; Lu et al., 2020), and mean grain size distributions for Toshan and Now Deh (Vlaminck et al., 2016; Kehl et al., 2021). Note that also Shah et al. (2021) reported grain size data from Kashmir which are dominated by silt.

ferent amounts of sand and are varying in their multimodal properties. Note that some multimodal properties may be measuring artefacts (cf. Schulte et al., 2018).

\section{Kashmir loess deposits within a Eurasian context}

Overall, $\chi$ properties of the studied sections in Kashmir are similar to loess in Eurasia, although the reference data were partly measured using different field frequencies and intensities. Figure 2c shows a comparison to magnetic enhancement from Semlac in Romania (Zeeden et al., 2016), Darai Kalon in Tajikistan (Jia et al., 2018), Toshan in Iran (Vlaminck et al., 2016) and the background susceptibility determined by Forster et al. (1994). The Kashmir loess shows higher $\chi$ than loess from Romania and lower values compared to loess from Tajikistan. Magnetic enhancement of Kashmir loess was quite strong during stadial phases of the last glacial cycle. Enhancement was partly even stronger than for full interglacial soils in Europe,but not as strong as in full interglacial soils in central Asia (Fig. 2c). Besides classical magnetic enhancement, an additional effect influences the relationship between $\chi_{\mathrm{If}}$ and $\Delta \chi$ leading to prominently elevated values of the $\chi_{\mathrm{lf}} / \Delta \chi$ ratio. We relate this to wind vigour effects (Begét and Hawkins, 1989) associated with strong winds delivering coarser material (with elevated $\chi_{\mathrm{lf}} / \Delta \chi$ ) from source areas in proximity to the studied LPS in Kashmir (Fig. 2). When comparing the Kashmir dataset to last glacial data from localities in Eurasia (using their respective age models; Fig. 2c), it becomes apparent that magnetic enhancement is similar to datasets from Romania and Iran. In contrast, magnetic enhancement of Tajik loess shows relatively elevated $\chi$ and/or reduced $\Delta \chi$. The dataset from Kashmir bridges these two data populations/trends and shows features of both. Kashmir grain size properties exhibit a $\sim 10 \mu \mathrm{m}$ median, and the grain size distribution is similar to loess from OIS 3 at Darai Kalon, Tajikistan (Lu et al., 2020; see Fig. 3), loess grain size at Toshan, Iran (Vlaminck et al., 2016), and loess at Now Deh, Iran (Kehl et al., 2021). At Toshan and Now Deh, finer grain sizes were interpreted to indicate the input of mineral dust from distal source areas (Kehl et al., 2021; Vlaminck et al., 2016). At Darai Kalon, the grain sizes $>25 \mu \mathrm{m}$ are considered to be driven by local near-surface wind intensity (Lu et al., 2020), which may be the case here, too. For the Kashmir loess, our grain size data indicate no sediment transport over the mostly $>2000 \mathrm{~m}$ high surrounding mountain ranges suggesting that the dust source is located in the Kashmir Valley or its direct surroundings. This implies 
that low $\mathrm{SiO}_{2} / \mathrm{AL}_{2} \mathrm{O}_{3}$ ratios reported by Ahmad and Chandra (2013) are a product of sediment origin besides transport, and possibly reworking of sedimentary rocks in Kashmir, and may not require transport over high mountain ranges. We interpret components around $\sim 100 / 150 \mu \mathrm{m}$ to indicate transport modes during strong wind events.

\section{Conclusions}

Magnetic enhancement of Kashmir loess was quite strong during stadial phases of the last glacial cycle. It reached interglacial intensity when compared to selected places in central Asia (Fig. 2c). Beside classical magnetic enhancement, an additional effect influences the relationship between $\chi_{\text {lf }}$ and $\chi_{\mathrm{fd}} / \Delta \chi$. We assign this to wind vigour with strong winds transporting coarser material with elevated $\chi_{\mathrm{lf}} / \Delta \chi$ ratios during the most loessic and coarse-grained intervals, pointing to local transport of a considerable amount of the material. The loess in Kashmir shows features of both "classical" magnetic enhancement (Forster et al., 1994) and wind-vigour effects. Grain sizes of Kashmir loess exhibit modes mostly around 5-20 $\mu \mathrm{m}$, similar to some data from central Asia ( $\mathrm{Lu}$ et al., 2020; Vlaminck et al., 2016; Kehl et al., 2021). Grain size distributions do not suggest transport over high mountain ranges that would be required for non-local sources in Kashmir. Therefore, and because of wind vigour effects, we suggest that the Kashmir loess is at least predominantly of local origin. The thick deposits of loess from the last glacial cycle in Kashmir (e.g. $>8, \sim 10, \sim 18 \mathrm{~m}$ for the last glacialinterglacial cycle; Dar and Zeeden, 2020; Meenakshi et al., 2018; Singhvi et al., 1987; Shah et al., 2021; and references in these) support this interpretation, as it appears unlikely that such substantial sediment masses were transported over the $>2000 \mathrm{~m}$ high mountain ranges surrounding Kashmir.

Data availability. The magnetic susceptibility and grain size data will be made available in the PANGAEA database.

Author contributions. CZ designed the study. Sampling was done by JAM, RAD and CZ. Samples were analysed by CL, MV, $\mathrm{CZ}$ and $\mathrm{CR}$. Interpretation and manuscript writing was led by $\mathrm{CZ}$ but was a joint effort of all authors (CZ, JAM, MV, CL, CR, RAD).

Competing interests. Christian Zeeden is an associate editor of $E \& G$ Quaternary Science Journal. The authors declare no other competing interests.

Disclaimer. Publisher's note: Copernicus Publications remains neutral with regard to jurisdictional claims in published maps and institutional affiliations.
Acknowledgements. We thank the staff of the Wanihama Middle School for providing the access to the Wanihama section and general support. Sumiko Tsukamoto is thanked for the fantastic teamwork in the framework of the project "Loess in India: recorder of the Indian Monsoon system". Samples were processed in the LIAG laboratories. We thank especially Kathrin Worm and Sonja Riemenschneider for their help with sample processing and measurements. We thank Hao Lu and Martin Kehl for sharing grain size data from Darai Kalon and Toshan, Now Deh, respectively. We also thank Tobias Sprafke and another reviewer for their constructive feedback through the review process, which helped to improve this article. This is IPGP contribution number 4235 .

Financial support. This research was funded by the Deutsche Forschungsgemeinschaft (DFG, German Research Foundation; grant no. 432194908).

Review statement. This paper was edited by Tobias Sprafke and reviewed by one anonymous referee.

\section{References}

Ahmad, I. and Chandra, R.: Geochemistry of loesspaleosol sediments of Kashmir Valley, India: Provenance and weathering, J. Asian Earth Sci., 66, 73-89, https://doi.org/10.1016/j.jseaes.2012.12.029, 2013.

Begét, J. E. and Hawkins, D. B.: Influence of orbital parameters on Pleistocene loess deposition in central Alaska, Nature, 337, 151153, https://doi.org/10.1038/337151a0, 1989.

Bronger, A., Pant, R. K., and Singhvi, A. K.: Pleistocene climatic changes and landscape evolution in the Kashmir Basin, India: Paleopedologic and chronostratigraphic studies, Quat. Res., 27, 167-181, https://doi.org/10.1016/0033-5894(87)90075-5, 1987.

Dar, R. A. and Zeeden, C.: Loess-Palaeosol Sequences in the Kashmir Valley, NW Himalayas: A Review, Front. Earth Sci., 8, 113 , https://doi.org/10.3389/feart.2020.00113, 2020.

Fischer, P., Jöris, O., Fitzsimmons, K. E., Vinnepand, M., Prud'homme, C., Schulte, P., Hatté, C., Hambach, U., Lindauer, S., Zeeden, C., Peric, Z., Lehmkuhl, F., Wunderlich, T., Wilken, D., Schirmer, W., and Vött, A.: Millennial-scale terrestrial ecosystem responses to Upper Pleistocene climatic changes: 4Dreconstruction of the Schwalbenberg Loess-Palaeosol-Sequence (Middle Rhine Valley, Germany), CATENA, 196, 104913, https://doi.org/10.1016/j.catena.2020.104913, 2021.

Forster, T., Evans, M. E., and Heller, F.: The frequency dependence of low field susceptibility in loess sediments, Geophys. J. Int., 118, 636-642, https://doi.org/10.1111/j.1365246X.1994.tb03990.x, 1994.

Jia, J., Lu, H., Wang, Y., and Xia, D.: Variations in the Iron Mineralogy of a Loess Section in Tajikistan During the Mid-Pleistocene and Late Pleistocene: Implications for the Climatic Evolution in Central Asia, Geochem. Geophy. Geosy., 19, 1244-1258, https://doi.org/10.1002/2017GC007371, 2018.

Kehl, M., Vlaminck, S., Köhler, T., Laag, C., Rolf, C., Tsukamoto, S., Frechen, M., Sumita, M., Schmincke, H.U., and Khormali, F.: Pleistocene dynamics of dust accu- 
mulation and soil formation in the southern Caspian Lowlands - New insights from the loess-paleosol sequence at Neka-Abelou, northern Iran, Quat. Sci. Rev., 253, 106774, https://doi.org/10.1016/j.quascirev.2020.106774, 2021.

Lu, H., Jia, J., Yin, Q., Xia, D., Gao, F., Liu, H., Fan, Y., Li, Z., Wang, X., Berger, A., Oimahmadov, I., and Gadoev, M.: Atmospheric dynamics patterns in southern central Asia since $800 \mathrm{ka}$ revealed by loess-paleosol sequences in Tajikistan, Geophys. Res. Lett., 47, e2020GL088320, https://doi.org/10.1029/2020GL088320, 2020.

Meenakshi, Kumar, P., Shrivastava, J. P., Chandra, R., Chopra, S., Roonwal, G. S., and Sharma, R.: High resolution 14C AMS ages $(\sim 50 \mathrm{ka})$ of organic matter associated with the loess-palaeosol Holocene-Late Pleistocene (8-130 ka) sediments of Dilpur Formation, Karewa Group, Kashmir, India, Quat. Geochronol., 47, 170-179, https://doi.org/10.1016/j.quageo.2018.06.004, 2018.

Schulte, P., Sprafke, T., Rodrigues, L., and Fitzsimmons, K. E.: Are fixed grain size ratios useful proxies for loess sedimentation dynamics? Experiences from Remizovka, Kazakhstan, Aeolian Res., 31, 131-140, https://doi.org/10.1016/j.aeolia.2017.09.002, 2018.
Shah, R. A., Achyuthan, H., Lone, A. M., Jaiswal, M. K., and Paul, D.: Constraining the timing and deposition pattern of loess-palaeosol sequences in Kashmir Valley, Western Himalaya: Implications to paleoenvironment studies, Aeolian Res., 49, 100660, https://doi.org/10.1016/j.aeolia.2020.100660, 2021.

Singhvi, A. K., Bronger, A., Pant, R. K., and Sauer, W.: Thermoluminescence dating and its implications for the chronostratigraphy of loess-paleosol sequences in the Kashmir Valley (India), Chem. Geol. Isot. Geosci. Sect., 65, 45-56, https://doi.org/10.1016/0168-9622(87)90061-3, 1987.

Vlaminck, S., Kehl, M., Lauer, T., Shahriari, A., Sharifi, J., Eckmeier, E., Lehndorff, E., Khormali, F., and Frechen, M.: Loess-soil sequence at Toshan (Northern Iran): Insights into late Pleistocene climate change, Quat. Int., 399, 122-135, https://doi.org/10.1016/j.quaint.2015.04.028, 2016.

Zeeden, C., Kels, H., Hambach, U., Schulte, P., Protze, J., Eckmeier, E., Marković, S. B., Klasen, N., and Lehmkuhl, F.: Three climatic cycles recorded in a loess-palaeosol sequence at Semlac (Romania) - Implications for dust accumulation in south-eastern Europe, Quat. Sci. Rev., 154, 130-142, https://doi.org/10.1016/j.quascirev.2016.11.002, 2016. 